This item was submitted to Loughborough's Research Repository by the author.

Items in Figshare are protected by copyright, with all rights reserved, unless otherwise indicated.

\title{
Keeping nuclear and other coastal sites safe from climate change
}

PLEASE CITE THE PUBLISHED VERSION

https://doi.org/10.1680/cien.2011.164.3.129

PUBLISHER

(C) ICE Publishing

VERSION

AM (Accepted Manuscript)

PUBLISHER STATEMENT

This work is made available according to the conditions of the Creative Commons Attribution-NonCommercialNoDerivatives 4.0 International (CC BY-NC-ND 4.0) licence. Full details of this licence are available at: https://creativecommons.org/licenses/by-nc-nd/4.0/

\section{LICENCE}

CC BY-NC-ND 4.0

\section{REPOSITORY RECORD}

Wilby, Robert L., Robert J. Nicholls, Rachel F. Warren, Howard S. Wheater, Derek Clarke, and Richard J. Dawson. 2019. "Keeping Nuclear and Other Coastal Sites Safe from Climate Change". figshare. https://hdl.handle.net/2134/37598. 


\section{Keeping nuclear and other coastal sites safe from climate change}

Wilby $^{1}$, R.L., Nicholls ${ }^{2}$, R.J, Warren ${ }^{3}$, R., Wheater ${ }^{4}$, H.S., Clarke $^{2}$, D., Dawson ${ }^{5}$, R.J.

${ }^{1}$ Department of Geography, Loughborough University, UK

${ }^{2}$ School of Civil Engineering and the Environment and Tyndall Centre for Climate Change Research, University of Southampton, UK

3 Tyndall Centre for Climate Change Research, School of Environmental Sciences, University of East Anglia, UK

${ }^{4}$ School of Environment and Sustainability, University of Saskatchewan, Canada

5 Tyndall Centre for Climate Change Research, Civil Engineering and Geosciences, Newcastle University, UK

Submitted to:

Proceedings of Institution of Civil Engineers

11 February 2011

Word count:

3996 (Abstract and main body text only)

\section{Corresponding author:}

Robert L. Wilby

Centre for Hydrological and Ecosystem Science,

Department of Geography,

Loughborough University,

Leicestershire, LE11 3TU

UK

Tel +44 1509223093

e-mail: r.l.wilby@lboro.ac.uk 


\begin{abstract}
Nuclear power is an important part of the UK Government's plan to improve energy security, and build a more balanced, decarbonised economy. Recent legislation establishes a framework for selecting potential sites for new nuclear build (NNB) and the terms for meeting the full costs of decommissioning and waste management. In this context, there are specific requirements to consider flood risk and to adapt to climate change. However, there is uncertainty about how climate risks might evolve and how these could be managed within each phase of a plant's life-cycle: design, operation, decommissioning and fuel storage. Given that sites will need to be secure for at least 160 years, the possibility of rising sea levels, higher sea temperatures, and more extreme weather events cannot be ignored. This paper describes the engineering and non-structural adaptation options for NNB sites, illustrated with reference to the east coast of England. Despite large uncertainty about climate scenarios for the 2200 s, we explain how flexibility of design and safety margins can be incorporated from outset and, when combined with routine environmental monitoring, how sites could be adaptively managed throughout their life-cycle.
\end{abstract}

\title{
Key words
}

Nuclear power plants; climate change; adaptation options; sea-level rise 


\section{Introduction}

The UK Government's Climate Change Act (2008) sets out a long-term commitment to reduce national emissions of greenhouse gases by $80 \%$ by 2050 . The UK Low Carbon Transition Plan ${ }^{1}$ contains five points of action: (1) protecting the public from immediate risks (such as heatwaves, flooding and coastal erosion); (2) factoring climate change into the design of new infrastructure and plans for natural resource management (such as water); (3) limiting global temperature increases to less than $2^{\circ} \mathrm{C}$ through international agreements on emissions; (4) building a low carbon economy with the immediate aim of cutting UK emissions by $34 \%$ by the 2020 s; (5) supporting individuals, communities and businesses in reducing their own emissions and adapting to unavoidable climate change. In short, the plan seeks to cut emissions whilst improving security of energy supply and maximising economic opportunities. This would be achieved through a mix of clean energy technologies such as renewables, nuclear, carbon capture and storage.

The scale of the challenge is daunting. First, the emission reduction targets must be achieved against a backdrop of aging power generation infrastructure, at least cost to the taxpayer, and with nature conservation in mind. By 2020 about one quarter of the UK's electricity generating capacity will need to be replaced ${ }^{2}$. Second, it is estimated that the UK economy would have to achieve annual rates of decarbonisation in excess of $4 \%$. This equates to $\sim 30$ new nuclear power stations to reach the 2006 carbon efficiency of France by $2015^{3}$. Third, the Severn Tidal Power scheme could provide up to $5 \%$ of current electricity generation, but the 2010 Feasibility Study concluded that costs to the taxpayer and risks to the environment would be excessive compared to other low-carbon energy options. Hence, at this time, the UK Government believes that a mix of nuclear power with wind energy, carbon capture and storage is a better option.

The aim of this paper is to consider how climate risks might evolve and be managed during the design, operation, decommissioning, and fuel storage phases of new nuclear build (NNB). We begin by outlining the legislative context to the latest era of nuclear power expansion. We then describe components of sea-level rise which potentially increase the risk of coastal erosion and flooding of the proposed NNB sites over the next two centuries. Despite the large uncertainty in regional climate change over these time-scales, we demonstrate that there are still a range of practical steps than can be taken to manage the evolving risks and maintain them at acceptable levels throughout the NNB life-cycle.

\section{Legislative context to new nuclear build}

The Planning Act (2008) introduced Energy National Policy Statements (NPSs). These set out the framework for approving nationally significant infrastructure for supplying low-carbon 
energy. Separate NPSs are provided for Fossil Fuels; Renewables; Gas Supply and Gas and Oil Pipelines; Electricity Networks; and Nuclear. The Strategic Siting Assessment (SSA) and Environmental Assessment processes (see Table 1) initially identified eleven sites in the vicinity of existing facilities that are potentially suitable for the deployment of new nuclear power stations. The Government subsequently rejected three of the sites primarily on environmental grounds (plus erosion and flood risks in the case of Dungeness). This left eight sites for further consideration. These are: Bradwell in Essex; Hartlepool; Heysham in Lancashire; Hinkley Point in Somerset; Oldbury in Gloucestershire; Sellafield in Cumbria; Sizewell in Suffolk; and Wylfa on Anglesey (Figure 1).

Separate provisions apply at the level of individual, prospective sites. The Energy Act (2008) demands that operators of new nuclear power stations meet in full their waste management, waste disposal and decommissioning costs. EU legislation further requires that before any new designs of nuclear reactors can be introduced they must first undergo high-level assessment to determine that economic, social and other benefits outweigh potential health and waste management detriments. Applications must also have due regard for a raft of planning policy statements (Table 2). For example, PPS1 challenges applicants to consider how their proposals for development contribute to reducing emissions and adapting to unavoidable climate change. PPS25 requires that flood risk be taken into account at all stages in the planning process to avoid inappropriate development in areas at risk of flooding, and directs development away from areas at highest risk. Despite the imperative for low-carbon energy in the NPS, due consideration must still be given to the relevant county Structure Plan and Local Plans of affected Districts. Public consultations are already underway for the Hinkley Point proposed nuclear development.

The Environment Agency has also provided operators with interim guidance for flood and coastal risk management at new nuclear station sites ${ }^{4}$. This explains the need for systematic monitoring of environmental indicators, periodic review, and sensitivity testing of plans in the context of climate change. Integrated modelling is revealing the extent to which flood and coastal erosion risks are connected by long-shore exchange of sediments and morphological change ${ }^{5}$. For example, where coastal defences are no longer maintained beyond the site perimeter, there could be beneficial sediment supply to the site's beach, but increased erosion/flood risk to neighbouring land that is beyond the control of the operator. Demonstrating that the works at new nuclear power sites will not cause or exacerbate coastal change/ erosion risk elsewhere will, therefore, require integrated assessment of the control exerted by multiple actors, including any adaptive management beyond the site foot print. Clearly, operators need to have an understanding of how the coast might change during the full life-cycle of the nuclear plant. 
Defra's standard guidance on managing flood and coastal risk management under climate change ${ }^{6}$ applies up to year 2115. However, the Environment Agency's draft principles ${ }^{4}$ recognise that the full life-cycle of a newly commissioned nuclear power plant could extend into the late 22nd century when accounting for the design ( $<10$ years), operation (>60 years), decommissioning ( $\sim 20$ years), and waste storage phases ( $~ 80$ years). The latest UK Climate Projections (UKCP09) ${ }^{7}$ do not directly assist with these latter decades, nor is any interim guidance offered on the 'credible maximum climate change scenario' for the period to 2200 . Furthermore, different adaptation objectives will apply at each life-cycle stage.

Finally, the Climate Change Act requires all companies with functions of a public nature ("reporting bodies") to prepare reports on how they are assessing and responding to the risks and opportunities presented by climate change.. Early reporting authorities, including National Grid Electricity Transmission, submitted reports in January 2011; electricity generators must provide adaptation plans by the end of July 2011. These risk assessments presume information on future physical characteristics such as coastal and river erosion which is clearly beyond the scope of UKCP09. Therefore, operators will need to develop their own projections to ensure that the main risks to assets and operations are covered. Developers must also adhere to the long-term obligations of environmental legislation such as the EU Water Framework Directive, and EU Habitats Directive.

\section{Extreme sea levels in the 21st century and beyond}

All proposed sites for NNB are located near the coast (Figure 1). Not surprisingly, risks posed by sea-level rise (SLR), coastal erosion and storm surges have figured prominently in analyses of long-term site integrity. The astronomical drivers of tidal cycles are well understood and are unlikely to change significantly in the near to mid-term (100-200 years). Relative sea-level change is mainly driven by a combination of climate-controlled and geologically-controlled components, which all need to be understood when developing local scenarios.

Given the utmost importance of nuclear safety, we present upper end estimates for each component based on the values reported by UKCP09 and the Delta Commission ${ }^{8}$ for 2100 and 2200, respectively. Indicative values are provided for the site at Sizewell on the east coast of England (Plate 1). UKCP09 refers to the High-plus-plus $(\mathrm{H++}$ ) scenario - a physically plausible, high-end scenario of indeterminate probability which provides a worst

\footnotetext{
i http://ww2.defra.gov.uk/environment/climate/sectors/reporting-authorities/
} 
case scenario for sensitivity testing across the range of possible futures. The $\mathrm{H++}$ scenario was utilised in the Thames Estuary 2100 Project which looked at the future of flood risk management in the Thames Estuary ${ }^{9}$. Over the course of the 21 st century and beyond, six major components of extreme sea level must be considered (labelled [a] to [f] in Table 3 and below):

a) Global-mean SLR as a result of the increase in the global volume of the ocean. UKCP09 cite an upper limit of $2.5 \mathrm{~m}$ for global mean SLR over the 21st century based on climate analogues (derived from Red Sea sediments and coral) ${ }^{10}$. The Delta Commission used a semi-empirical approach ${ }^{11}$ and, assuming a global mean temperature increase of up to $8^{\circ} \mathrm{C}$ by 2200 , arrived at an upper limit of $3.5 \mathrm{~m}$ for global mean ocean expansion. Projected changes in ocean volume are primarily due to:

(i) Thermal expansion of the upper ocean as it warms;

(ii) Melting of small glaciers and ice caps;

(iii) Contribution of the Greenland (GIS) and Antarctic ice sheets ${ }^{12}$. Until recently, the Antarctic ice sheet was expected to grow in size due to increased snowfall, producing a small fall in sea level, while the Greenland ice sheet, being much more sensitive to changes in temperature, was expected to lose mass. However, recent observations of the Greenland ice sheet show rapid rates of melting with consequent upward revisions of its contribution to sea-level rise. Renewed concern about instability of the West Antarctic Ice Sheet (WAIS) has raised the possibility of a large positive contribution to sea-level from Antarctica during the 21 st Century and beyond ${ }^{13}$.

(v) Direct human influence on sea level due to modifications to the hydrological cycle, including global groundwater depletion, impoundment of water in reservoirs and land drainage. As these processes have both positive and negative effects on sea level, the net effect could be small or negligible.

b) Regional spatial variations in sea-level change as a result of gravitational effects arising from the redistribution of mass due to the melting of land-based ice. When ice masses melt the local gravitational pull decreases and sea levels fall in the near vicinity. Further afield SLR may be greater than the global mean. The uneven and shifting loads also cause the solid Earth to deform thereby affecting the gravity field and producing a distinctive pattern of SLR. Local estimates for this gravitational 'fingerprint' vary enormously. For example, the Delta Commission used scaling factors spanning 1.1 to 2.6 for Antarctic ice and 0.2 to -2.5 
for the GIS when estimating the contribution of each to SLR along the Dutch coast ${ }^{8}$. The overall UK/global mean SLR ratio used by UKCP09 was 0.76 for 2100.

c) Regional spatial variations in sea level change as a result of oceanographic factors such as differences in the rates of oceanic thermal expansion, changes in long-term wind and atmospheric pressure, and changes in ocean circulation (such as the Gulf Stream). While it is agreed that these factors could be significant, causing large regional departures of up to $50-100 \%$ from the global average value of the thermal expansion component of sea-level rise, coupled ocean-atmosphere climate models of these effects under global warming show little agreement on where these deviations might occur. Collapse of the thermohaline circulation is thought to be unlikely by 2100 , but an additional allowance of $0.6 \mathrm{~m}$ was made by the Delta Commission for local expansion in the North Atlantic Ocean by 2200.

d) Regional variations and trends in sea level as a result of vertical land movements (uplift and subsidence), due to various natural and human-induced geological processes. While the Earth's surface may appear stable, vertical land movement is almost universal to varying degrees. Natural causes include tectonics, neotectonics (including glacio-isostatic adjustment), and sediment compaction/consolidation. In the UK, these changes are usually slow and steady due to the absence of earthquakes. However, human activity may increase local rates of subsidence in susceptible coastal lowlands via land reclamation, lowering water tables through water extraction and improved drainage, and peat destruction due to oxidation and erosion. UKCP09 employed the results of a Glacial Isostatic Adjustment (GIA) model constrained by observations ${ }^{14}$ to estimate vertical land movements around the UK. This yields a local estimate of $\sim 0.1 \mathrm{~m} /$ century for the east coast of England and this rate is assumed to apply to 2200 .

e) Regional variations in tidal surge magnitude due to long-term changes in wind and storminess. When low pressure systems track across the ocean they cause the underlying water column to 'bulge'. The magnitude of the surge depends on the minimum pressure and wind speeds, as well as on funnelling effects by coastline features and estuaries. Atlantic storm frequency and intensity vary from year to year, decade to decade, and century to century, so any trends are hard to detect. Future climate-driven changes in surges are expected to lie within historic variability for the UK coastline (see for example Figure 2). However, the climate model with the largest increase in storminess over the UK region yields an upper end change in the surge of $+1.3 \mathrm{~m}$ for the east coast ${ }^{7}$. 
f) Regional variations in significant wave height due to long-term changes in wind strength and direction, combined with any local adjustments to shoreline and offshore bathimetry. There is relatively limited information on changing wave conditions. It is generally accepted that wave heights have increased in the boreal winter over the past half century in the highlatitudes of the northern hemisphere (especially in parts of the North Atlantic) ${ }^{16}$. The Delta Commission concluded that projected changes in the wave climate are small relative to natural variability, vary between climate models because of their differing wind fields, and are insensitive to the greenhouse gas emissions scenario. Relatively short observational records further compound the large uncertainty in wave statistics. This uncertainty is reflected in the range of UKCP09 projections of future wave climate which span $-35 \mathrm{~cm}$ to +5 $\mathrm{cm}$ for changes in the winter mean wave height, and $-1.5 \mathrm{~m}$ to $+1 \mathrm{~m}$ for the annual maxima.

\section{Adaptation options for new nuclear build sites}

Table 3 shows that in the worst case, the above components could linearly combine to change extreme water levels by up to $+4.3 \mathrm{~m}$ by 2100 and up to $+5.8 \mathrm{~m}$ by 2200 . Figure 3 shows extreme water levels excluding changes in the wave environment. Since the various constituents arise from different sources it is not possible to attach return periods or probabilities to the resulting levels. Indeed, estimation of the nuclear industry standard $10^{-5}$ event is problematic under any circumstances let alone for 2200 . This implies that additional techniques for managing risk are needed beyond a conventional scenario-led approach.

Other disciplines are increasingly turning to vulnerability-led or "bottom up" methods of adapting to uncertain climate change. It is recognised that societal responses to climate hazards can take many different forms, ranging from changes in behaviour to reduce risk exposure, through to major investments in new assets to protect vital infrastructure, and/or better forecasting and contingency planning (Table 4). Robust adaptation measures are typically low regret, reversible, incorporate safety margins, employ 'soft' solutions (that is adjustments to operational practice), flexibility and yet are mindful of actions being taken by others to either mitigate or adapt to climate change, as well as other relevant drivers ${ }^{17}$.

Anticipatory (or proactive) adaptation at the level of NNB sites requires different types of evidence and approach at different phases in the project life-cycle (Table 5). Two contrasting design strategies might be adopted. On the one hand, large safety margins might be incorporated within the design, accompanied by systematic monitoring and maintenance. Here adaptation to a specified amount of climate change is factored from outset. On the other hand, designs with smaller freeboard, yet greater capacity for more frequent upgrade and retrofit might be incorporated. This strategy puts more emphasis on continued surveillance of risks, as well as on corporate and regulatory stability over many decades. 
During the design phase, the latest climate projections and expert judgements of hazards can be incorporated within safety margins for fundamental elements such as platform level. [Indeed, the UK nuclear power industry is already assimilating knowledge of the extreme levels described in Table 4]. Potentially vulnerable features of the overall design can be identified (such as internal flooding via cooling system ingress) and constructed to much higher standards. Modelling can be used to explore potential changes in the behaviour of the heat sink or the future distribution of marine species such as jelly-fish and eel. This information could be used in the specification of new cooling water intakes and outfalls (Plate 2). Modular designs, particularly for components most sensitive to SLR, and set aside of land can help build flexibility and contingency within the site plan to accommodate large uncertainty in rates of SLR, coastal erosion and flooding.

As noted above, it is critical that monitoring systems are established so that data on evolving hazards and conditions on/around the site can help plan for any retro-fit or upgrade throughout the operational life-time. Indeed, real-time information on changing environmental factors and asset conditions is critical to adaptive management within a periodic review process. The data inventory should include repeat, high-resolution surveys of shoreline position and elevation, routine measurement of tide and wave heights, marine biota, and in situ meteorology. Much of this information is required for shoreline management at the subcell and cell levelii, so there is scope for coordination and cost-saving.

The operational phase may last more than 60 years. During this time, the plant will be subject to periodic safety reviews and legislation to minimise environmental impact (Table 5). Co-benefits may arise from shared strategies for managing the coastal zone with neighbouring land-owners. For example, SLR may accelerate erosion of the headlands to the north of Sizewell and ultimately inundate the Minsmere nature reserve (Plate 3 ). This may help to nourish the foreshore of Sizewell (Plate 1) but could lead to the loss of valuable coastal habitats without a shared plan for managed realignment. Higher ocean temperatures have already extended the northerly geographical range of fish species such as sardine, anchovy, red mullet and bass, and been linked to extensive restructuring of phytoplankton and zooplankton communities in the North Atlantic. Thermal discharges to the coastal zone could place greater heat stress on protected species at the southern limits of their range in these environments. Again, routine monitoring would be an essential means of tracking any additional impacts of the plant on long-term environmental quality. If the pace of change accelerates, the cycle length of periodic reviews could be reduced.

\footnotetext{
ii http://www.defra.gov.uk/environment/flooding/documents/policy/guidance/smpguide/smpgvol1.pdf
} 
Power plant owners will also want to keep disruption of operations to a minimum (such as bio-fouling of intakes, recirculation of the thermal plume, temporary reductions in the heat sink efficiency, flooding or wave over-topping damage to infrastructure). Changes in the marine environment and storminess could reduce the economic performance of the plant through more frequent outages or higher pumping and refuelling costs. Periodic upgrading to higher specifications when screens or pumps are replaced could help counteract these concerns. Longer-lead and/or more accurate extreme weather forecasts could facilitate rescheduling of maintenance or trigger contingency plans.

Ahead of de-commissioning (Table 5) there will be a need for visioning of future conditions and land-use options at the site, extending well into the 22nd century and beyond. There is no universal blueprint for adaptation, not least because there is no single adaptation pathway or 'end point'. But there is consensus amongst climate models that the SLR commitment is for centuries to come $^{18}$. Furthermore, unless there is stabilization of greenhouse gas concentrations, the risk of abrupt climate change - leading to rapid changes in mean sea level - is expected to increase with time ${ }^{19}$. Therefore, ahead of the decommissioning and fuel storage phases the onus must be on planning for the long-term security and integrity of the site. Depending on the pace of SLR it may be necessary to redesign, raise, or increase protection of repositories. It is not inconceivable that some sites could eventually become headlands or even islands, heavily defended against tidal erosion, flooding and wave attack. The ultimate adaptation solution would be to relocate the stored material.

Finally, we should keep in mind that the institutional and societal priorities of that time are unlikely to resemble those of today. There should also be a further century of monitoring and scientific endeavour to support decision-making. For instance, decade to decade variations in North Atlantic storminess might be better understood and predicted. However, the companies that installed the power plants may no longer exist, so some thought is needed about continuity management and regulation of the sites.

\section{Conclusions}

The summer heat wave of 2003 reminded the international nuclear power industry of the risks posed by extreme weather and climate change ${ }^{20}$. Since then, nuclear power has become an even more important part of the UK Government's plan to improve energy security, and move towards a decarbonised economy. All proposed sites for NNB are located on or near the coast. Therefore, risks posed by rising sea levels, coastal erosion and flooding figure prominently in assessments of site integrity. However, the life-cycle of the new plants extends well into the 22nd century, a time horizon for which there is very little 
climate risk information in general, and especially at the site scale. Furthermore, several important components of extreme sea level are poorly understood, leading to large uncertainty bounds in climate model projections. Nonetheless, physically plausible upper limit estimates indicate that extreme water levels (net sea level plus tidal surge plus significant waves) on the east coast of England could change by up to $+4.3 \mathrm{~m}$ by 2100 and by up to $+5.8 \mathrm{~m}$ by 2200 .

Extreme sea levels are already being employed in safety margins in the design proposals for NNB sites such as Hinkley Point and Sizewell. The challenge is to make these stations robust in the face of great uncertainty. Recognising this need, other steps can be taken to adaptively manage climate risks at these sites. For example: forethought in the building layout and set aside of land within the site footprint; application of higher standards of design especially for the most climate vulnerable elements; and modular design to enable lower-cost retrofit, upgrade and replacement. Modelling can be used to evaluate the performance of specific design options and for integrated assessment of flood and coastal erosion risks that may be activated beyond the site itself. Above all, the risk will not change suddenly and appropriate monitoring and forecasting can support operations and periodic risk assessment to trigger the necessary risk management strategies. Such activities will benefit from greater clarity in the position of the regulators concerning long term risk from climate change, and from open and informed dialogues between the industry and government. Given the global renaissance in nuclear power, the lessons currently being learnt in the UK could have far-reaching influence on practise elsewhere. Furthermore, many of the adaptation principles developed for nuclear plants could find wider application to infrastructure development in the coastal zone more generally.

\section{Acknowledgements}

The authors thank Paul Buckley, Chris Kilsby, Andy Payne, John Pinnegar, Stephen Roast, and Colin Taylor for their constructive remarks on earlier versions of this paper.

\section{References}

1 HM Government, 2009. The UK Low Carbon Transition Plan: National strategy for climate and energy. Department of Energy and Climate Change, The Stationary Office, 220pp.

2 Statement on Energy Policy by Chris Huhne (Written Ministerial Statement) The Rt. Hon. Chris Huhne MP: Secretary of State for Energy and Climate Change 18 October 2010.

3 Pielke, R.A. Jr. 2009. The British Climate Change Act: a critical evaluation and proposed alternative approach. Environmental Research Letters, 4, 1-7.

4 Environment Agency, 2010. Principles for Flood and Coastal Risk Management at New Nuclear Power Stations in England and Wales. Environment Agency, New Nuclear Build, Environment and Business, Bristol, 6pp. 
5 Dawson, R.J., Dickson, M.E., Nicholls, R.J., Hall, J.W., Walken, M.J.A., Stansby, P.K., Mokrech, M., Richards, J., Zhou, J., Milligan, J., Jordan, A., Pearson, S., Rees, J., Bates, P.D., Koukoulas, S. and Watkinson, A.R. 2009. Integrated analysis of risks of flooding and cliff erosion under scenarios of long term change. Climatic Change, 95, 249-288.

6 Department for Environment, Food and Rural Affairs (Defra), 2006. Flood and Coastal Defence Appraisal Guidance, FCDPAG3 Economic Appraisal, Supplementary Note to Operating Authorities - Climate Change Impacts. DEFRA, London, 9pp. http://www.defra.gov.uk/environment/flooding/documents/policy/guidance/fcdpag/fcd3clim ate.pdf [Accessed 15.10.10]

7 Lowe, J. A., Howard, T., Pardaens, A., Tinker, J., Holt, J., Wakelin, S., Milne, G., Leake, J., Wolf, J., Horsburgh, K., Reeder, T., Jenkins, G., Ridley, J., Dye, S. and Bradley, S. 2009. UK Climate Projections science report: Marine and coastal projections. Met Office Hadley Centre, Exeter, UK.

8 Vellinga, P., Katsman, C., Sterl, A., Beersma, J., Hazeleger, W., Church, J., Kopp, R., Kroon, R., Oppenheimer, M., Plag, H.-P., Rahmstorf, S., Lowe, J., Ridley, J., von Storch, H., Vaughan, D., van de Wal, R., Weisse, R., Kwadijk, J., Lammersen, R. and Marinova, N. 2009. Exploring high-end climate change scenarios for flood protection of the Netherlands. KNMI Scientific Report, 2009-05, de Bilt, Netherlands, 150pp.

9 Environment Agency, 2009. TE2100 Plan Consultation Document. Thames Barrier, London.

10 Rohling, E.J., Grant, K., Hemleben, CH., Siddall, M., Hoogakker, B.A.A., Bolshaw, M. and Kucera, M. 2008. High rates of sea-level rise during the last interglacial period. Nature Geoscience, 1, 38-42.

11 Rahmstorf, S. 2007. A semi-empirical approach to projecting future sea-level rise. Science, 315, 368-370.

12 Velicogna, I. 2009. Increasing rates of ice mass loss from the Greenland and Antarctic ice sheets revealed by GRACE. Geophysical Research Letters, 36, L19503.

13 Bamber, J.L., Riva, R.E.M., Vermeersen, B.L.A. and LeBroq, A.M. 2009. Reassessment of the potential sea-level rise from a collapse of the West Antarctic Ice Sheet. Science, 324, 901-903.

14 Bradley, S., Milne, G.A., Teferle, F.N., Bingley, R.M. and Orliac, E.J. 2008. Glacial isostatic adjustment of the British Isles; New constraints from GPS measurements of crustal motion. Geophysical Journal International, 178, 14-22.

15 Wilby, R.L. 2008. Downscaling future skew surge statistics at Sheerness, Kent. Phase 3 studies - synthesis report. Thames Estuary 2100, Environment Agency, 27pp.

16 Wang, X.L., Swail, V.R., Zwiers, F.W., Zhang, X. and Feng, Y. 2009. Detection of external influence on trends of atmospheric storminess and northern oceans wave heights. Climate Dynamics, 32, 189-203.

17 Hallegatte, S. 2009. Strategies to adapt to an uncertain climate change. Global Environmental Change, 19, 240-247.

18 Eby, M., Zickfeld, K., Montenegro, A., Archer, D., Meissner, K.J. and Weaver, A.J. 2009. Lifetime of anthropogenic climate change: Millennial time scales of potential $\mathrm{CO} 2$ and surface temperature perturbations. Journal of Climate, 22, 2501-2511.

19 Lenton, T.M., Held, H., Kriegler, E., Hall, J.W., Lucht, W., Rahmstorf, S. and Schellnuber, H.J. 2008. Tipping elements in the Earth's climate system. Proceedings of the National Academy of Sciences of the Unites States of America, 105, 1786-1793.

20 Manoha, B., Hendrickx, F., Dupeyrat, A., Bertier, C. and Parey, S. 2008. Impact des evolutions climatiques sur les activités d'EDF (projet impec). La Houille Blanche, 2, 5560. 
Table 1 UK Government's criteria for evaluating site suitability in the Strategic Siting Assessment (SSA). Criteria shown in bold italics are potentially affected by climate change.

- Demographics

- Proximity to military activities

- Flooding

- Coastal processes

- Proximity to hazardous industrial facilities

- Proximity to civil aircraft movements

- Internationally designated sites of ecological importance

- Nationally designated sites of ecological importance

- Areas of amenity, cultural heritage and landscape value

- Size of site to accommodate operation

- Access to suitable sources of cooling

Table 2 Planning policy statements (PPS) affecting new nuclear site proposals in the UK.

- PPS1: Delivering Sustainable Development (and the Climate Change Supplement)

- PPS4: Planning for Sustainable Economic Growth

- PPS5: Planning for the Historic Environment

- PPS9: Biodiversity and Geological Conservation

- PPS25: Development and Flood Risk

- PPG13: Transport

- PPG17: Open Space, Sport and Recreation

- PPG20: Coastal Planning 
Table 3 Worst case components of extreme water levels $(\mathrm{m})$ for 2090-2099 and 2200 relative to 1990 for the east coast of England. All values are rounded to the nearest $0.1 \mathrm{~m}$. Figures for 2100 are based on the assumptions of the UKCP09 $\mathrm{H}++$ scenario ${ }^{7}$.

\begin{tabular}{|l|c|c|l|}
\hline Component & $\begin{array}{c}\mathbf{2 1 0 0} \\
\text { (UKCP09) }\end{array}$ & $\begin{array}{c}\mathbf{2 2 0 0} \\
\text { (various) }\end{array}$ & Comments for 2200 \\
\hline $\begin{array}{l}\text { [a] Global mean sea-level rise } \\
\text { due to ice melt plus thermal } \\
\text { expansion }\end{array}$ & +2.5 & +3.5 & $\begin{array}{l}\text { Assumes Delta Commission upper } \\
\text { estimate for global mean sea-level rise due } \\
\text { to partial melt of GIS, WAIS and small } \\
\text { glaciers combined with thermal expansion }\end{array}$ \\
\hline $\begin{array}{l}\text { [b] adjustment for UK mean } \\
\text { sea-level rise to reflect elastic } \\
\text { and gravitational effects }\end{array}$ & -0.6 & -0.8 & $\begin{array}{l}\text { Assumes local/global mean ratio } \\
\text { ("fingerprint") of 0.76 (as in UKCP09) }\end{array}$ \\
\hline $\begin{array}{l}\text { [c] plus local expansion of the } \\
\text { North Atlantic Ocean due to } \\
\text { the collapse of the } \\
\text { thermohaline circulation }\end{array}$ & - & +0.6 & $\begin{array}{l}\text { Assumes upper estimate of the Delta } \\
\text { Commission }\end{array}$ \\
\hline $\begin{array}{l}\text { [d] plus vertical land movement } \\
\text { (east coast of England) }\end{array}$ & +0.1 & +0.2 & Assumes +0.1 m per century \\
\hline $\begin{array}{l}\text { [e] plus the tidal surge (east } \\
\text { coast) }\end{array}$ & +1.3 & +1.3 & $\begin{array}{l}\text { Assumes no change to the 1 in 50 year } \\
\text { skew surge given by UKCP09 or any } \\
\text { change in surge-tide interactions from } \\
\text { 2100 }\end{array}$ \\
\hline $\begin{array}{l}\text { [f] plus change in annual } \\
\text { maximum significant wave } \\
\text { height (east coast) }\end{array}$ & +1.0 & +1.0 & $\begin{array}{l}\text { Assumes no change in significant wave } \\
\text { height from 2100 }\end{array}$ \\
\hline $\begin{array}{l}\text { Net change in extreme water } \\
\text { level (m) }\end{array}$ & +4.3 & +5.8 & \\
\hline
\end{tabular}

Table 4 Typology of practical steps being taken by organizations to adapt to climate change

\begin{tabular}{|l|l|}
\hline Adaptation types & Example activities \\
\hline New infrastructure & Surface water impoundments; flood defence systems \\
Resource management & Assess natural resource availability, adjust scheduling or allocation; reduce co-stressors \\
Retrofit & Upgrade infrastructure to cope with more frequent and/or severe extreme events \\
Behavioural & Forecasts to increase preparedness and guide risk reduction measures \\
Institutional & Regulation, monitoring and reporting to maintain or improve levels of service and safety \\
Sectoral & Economic planning, sector restructuring; professional guidance, standards and codes \\
Communication & Raise awareness of risks to vulnerable groups; high-level advocacy and policy triggers \\
Financial & Spread risk by insurance services; incentives to change behaviour \\
\hline
\end{tabular}


Table 5 Summary of risks, evidence and adaptation options for new nuclear build sites over the course of more than 150 years planned life-cycle

\begin{tabular}{|c|c|c|c|}
\hline Phase & Considerations & Evidence & Adaptation measures \\
\hline $\begin{array}{l}\text { Consent, design } \\
\text { and construction } \\
\text { (<10 years) }\end{array}$ & $\begin{array}{l}\text { National Planning Statement } \\
\text { Platform level } \\
\text { Flood erosion and defence line } \\
\text { Beach nourishment } \\
\text { Heat sink, recirculation and } \\
\text { siltation } \\
\text { Site access } \\
\text { Vulnerable elements within } \\
\text { overall design (cooling system } \\
\text { ingress) } \\
\text { Site drainage } \\
\text { Impact on Protected Areas } \\
\text { Other major infrastructure plans }\end{array}$ & $\begin{array}{l}\text { High-resolution } \\
\text { topographic survey of } \\
\text { sites and shoreline } \\
\text { position } \\
\text { HSE hazard metrics } \\
\text { Probabilistic scenarios } \\
\text { Expert judgement (H++ } \\
\text { scenario) } \\
\text { Marine/estuary } \\
\text { modelling } \\
\text { Data on joint } \\
\text { occurrence of extremes } \\
\text { Fluvial flood and } \\
\text { geomorphological } \\
\text { scenarios } \\
\text { Socio-political } \\
\text { scenarios } \\
\text { Bioclimatic envelope } \\
\text { modelling }\end{array}$ & $\begin{array}{l}\text { Incorporate safety } \\
\text { margins } \\
\text { Sensitivity testing of } \\
\text { options } \\
\text { Set aside for retrofit and } \\
\text { storage } \\
\text { Modular or flexible design } \\
\text { Apply higher standards of } \\
\text { design to most vulnerable } \\
\text { elements } \\
\text { Design monitoring and } \\
\text { review programme } \\
\text { Install monitoring } \\
\text { systems }\end{array}$ \\
\hline $\begin{array}{l}\text { Operational } \\
(60+\text { years })\end{array}$ & $\begin{array}{l}\text { Re-fuelling } \\
\text { Pumping water/ energy costs } \\
\text { Periodic safety review (every } 10 \\
\text { years) } \\
\text { Economic performance } \\
\text { Disruption to supply chains } \\
\text { Legislation (e.g., WFD, National } \\
\text { Climate Change Risk } \\
\text { Assessment, Marine Protected } \\
\text { Zones, Marine Strategy } \\
\text { Framework, Shoreline } \\
\text { Management Plans) } \\
\text { Heat sink, recirculation and } \\
\text { siltation } \\
\text { Bio-fouling and entrainment } \\
\text { (frequency and seasonality) } \\
\text { Management of neighbouring } \\
\text { land along the coast/estuary }\end{array}$ & $\begin{array}{l}\text { Shoreline and } \\
\text { sandbank positions } \\
\text { Storm intensity } \\
\text { Wave environment } \\
\text { Extreme precipitation } \\
\text { Heat-waves } \\
\text { Extreme tidal levels } \\
\text { (high and low) } \\
\text { Joint occurrence of } \\
\text { extremes } \\
\text { Marine species } \\
\text { distributions }\end{array}$ & $\begin{array}{l}\text { Early warning systems } \\
\text { Routine monitoring and } \\
\text { review of evolving } \\
\text { hazards and marine } \\
\text { ecosystems } \\
\text { Detailed survey of } \\
\text { coastal defence and flood } \\
\text { protection assets } \\
\text { Identify trigger points for } \\
\text { change } \\
\text { Upgrade to higher } \\
\text { specification on } \\
\text { replacement/retro-fit } \\
\text { Adjust periodic review } \\
\text { cycle-length as required } \\
\text { Create new habitats (to } \\
\text { compensate for losses) } \\
\text { Develop shared strategy } \\
\text { with neighbours for } \\
\text { managing the } \\
\text { coast/estuary }\end{array}$ \\
\hline $\begin{array}{l}\text { Decommissioning } \\
\text { (20 years) }\end{array}$ & $\begin{array}{l}\text { De-fuelling } \\
\text { Dismantling site } \\
\text { Storing residual hazard }\end{array}$ & $\begin{array}{l}\text { Post } 2100 \text { climate } \\
\text { scenarios }\end{array}$ & $\begin{array}{l}\text { Routine monitoring and } \\
\text { review of evolving } \\
\text { hazards and marine } \\
\text { ecosystems } \\
\text { Create new habitats }\end{array}$ \\
\hline $\begin{array}{l}\text { Fuel storage } \\
(80+\text { years })\end{array}$ & $\begin{array}{l}\text { Risk target of } 10^{-6} / \mathrm{yr} \text { for serious } \\
\text { health effects } \\
\text { Site security } \\
\text { Post-institutional (passive) use(s) }\end{array}$ & $\begin{array}{l}\text { Climate scenarios to } \\
2200 \\
\text { Simulation of long-term } \\
\text { coastal evolution }\end{array}$ & $\begin{array}{l}\text { Redesign, raise and/or } \\
\text { protect storage areas } \\
\text { Monitoring of site and } \\
\text { environmental pathways } \\
\text { Physical relocation }\end{array}$ \\
\hline
\end{tabular}


Figure 1 Nominated sites for new nuclear power stations, October 2010. Source: DECC

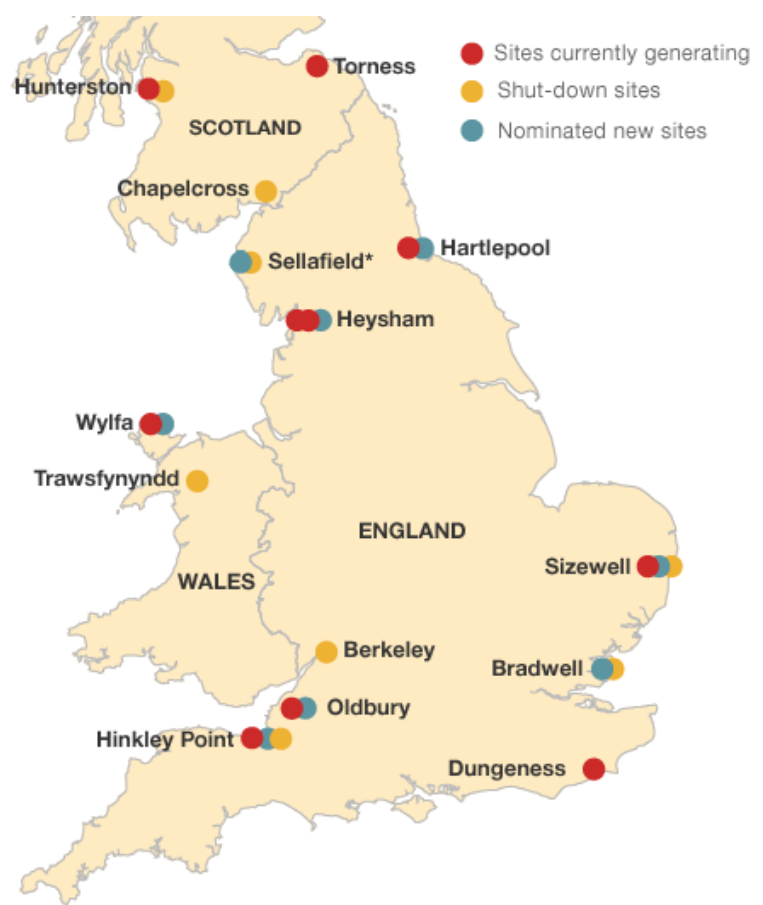

Figure 2 Annual maximum skew surge for the years 1961-2100 downscaled to the Thames Estuary at Sheerness from four climate models: CGCM2 (red), CSIRO (orange), ECHAM4 (green) and HadCM3 (blue) ${ }^{15}$. The skew surge is the difference between the highest measured water level in a tidal cycle (irrespective of timing) and the expected (astronomical) high water level. The black line shows the observed skew for years 1961-2000. Series of observed and downscaled surges would not be expected to match year to year, but interannual variability should be similar.
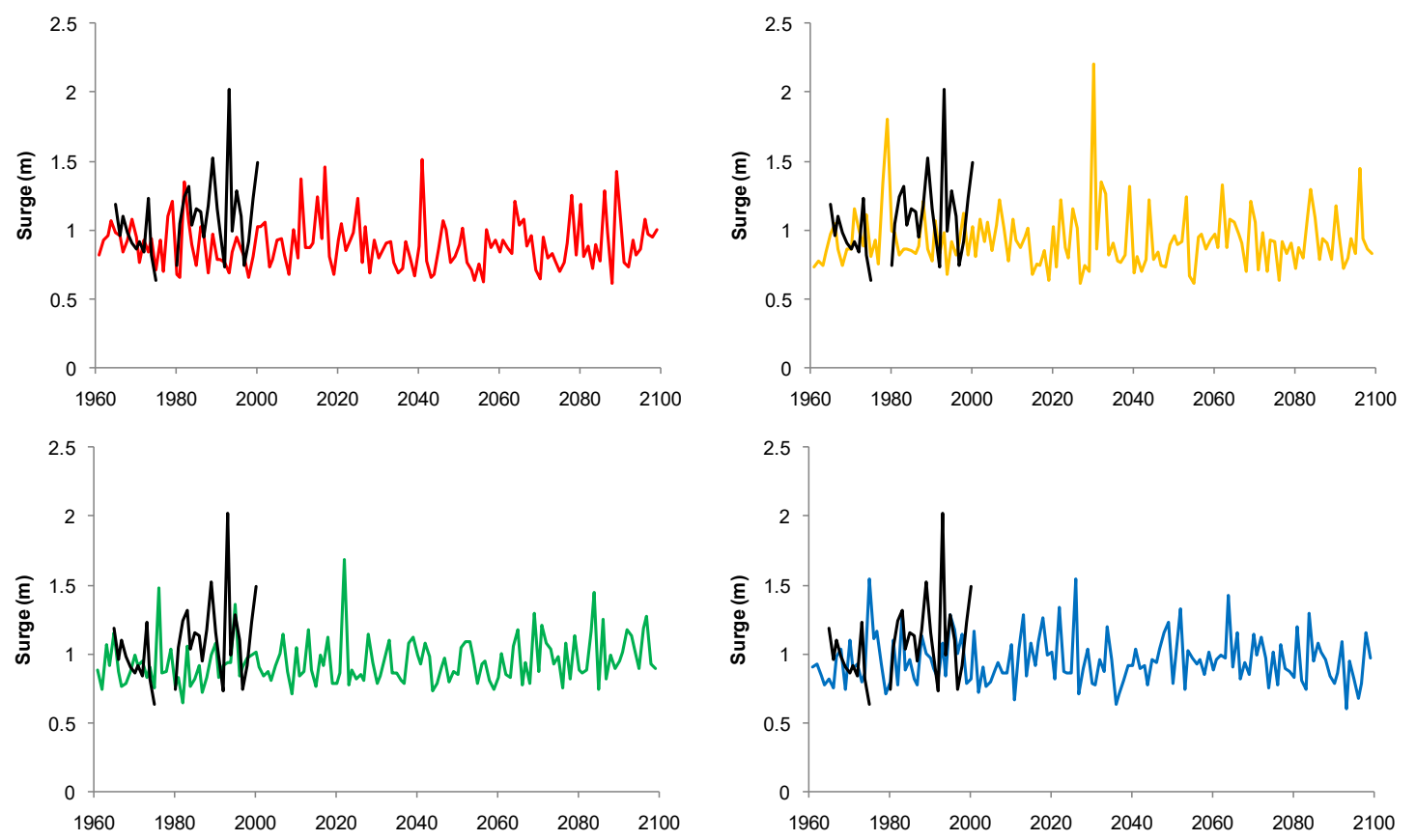
Figure 3 UKCP09 upper limit increase in 1:50 year extreme sea levels $(\mathrm{cm})$ around the UK coast by 2090-2099. The values are based on regional variations in vertical land movements combined with the upper limit of sea level change and high end $\mathrm{H}++$ skew surge ${ }^{7}$.

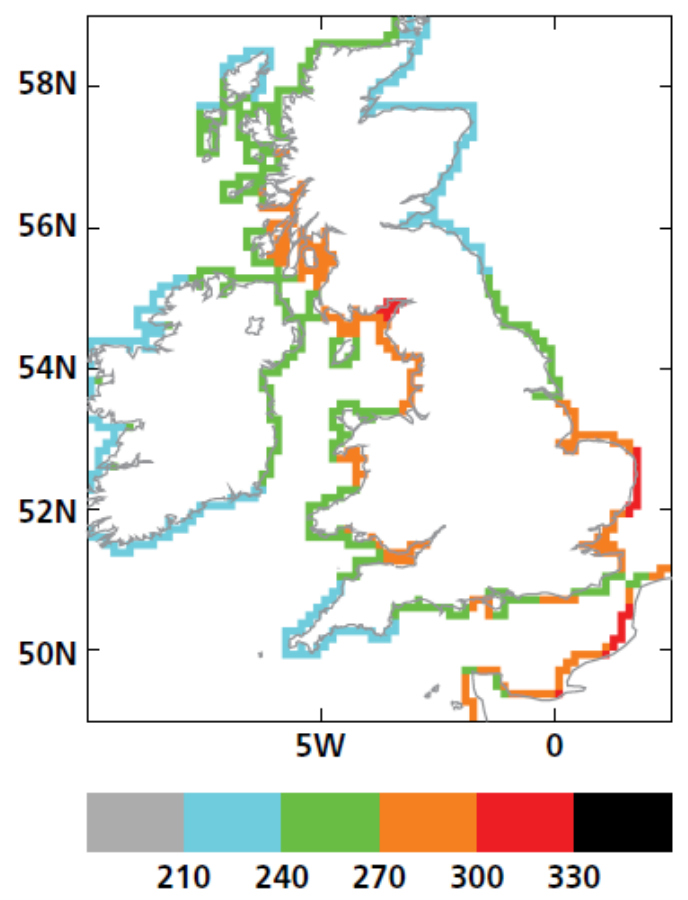


Plate 1 Sizewell B and foreshore

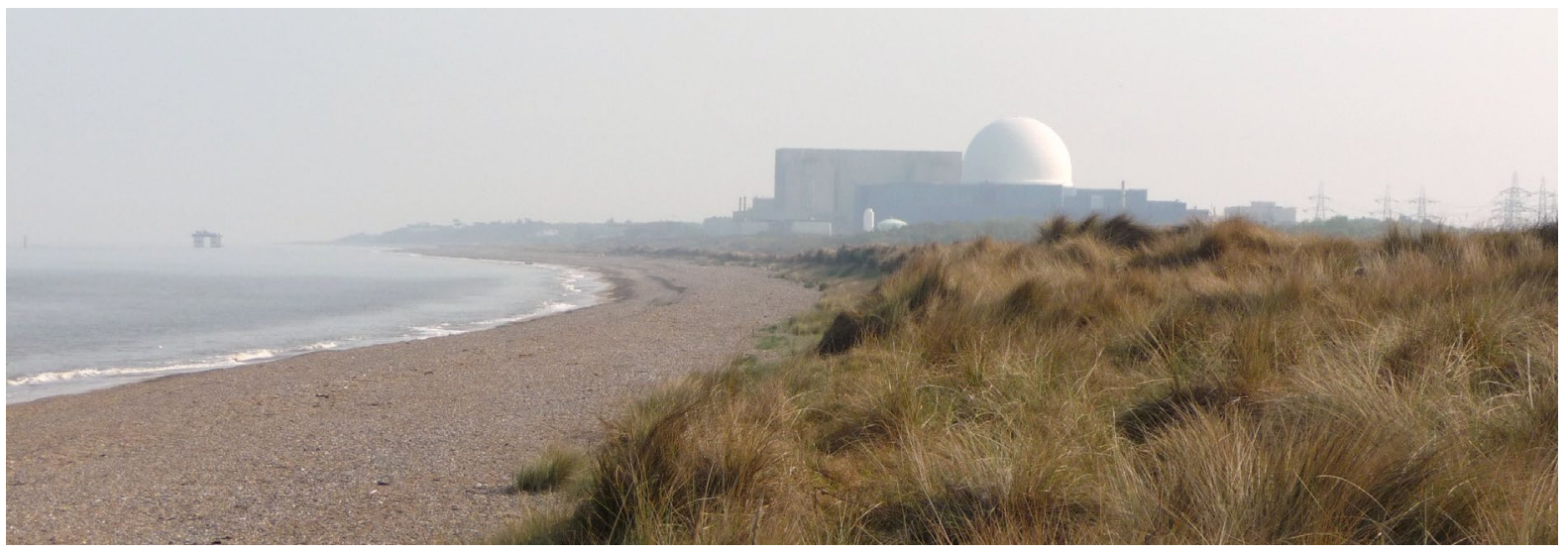

Plate 2 The (decommissioning) Sizewell A station (Magnox) cooling water outfall headworks

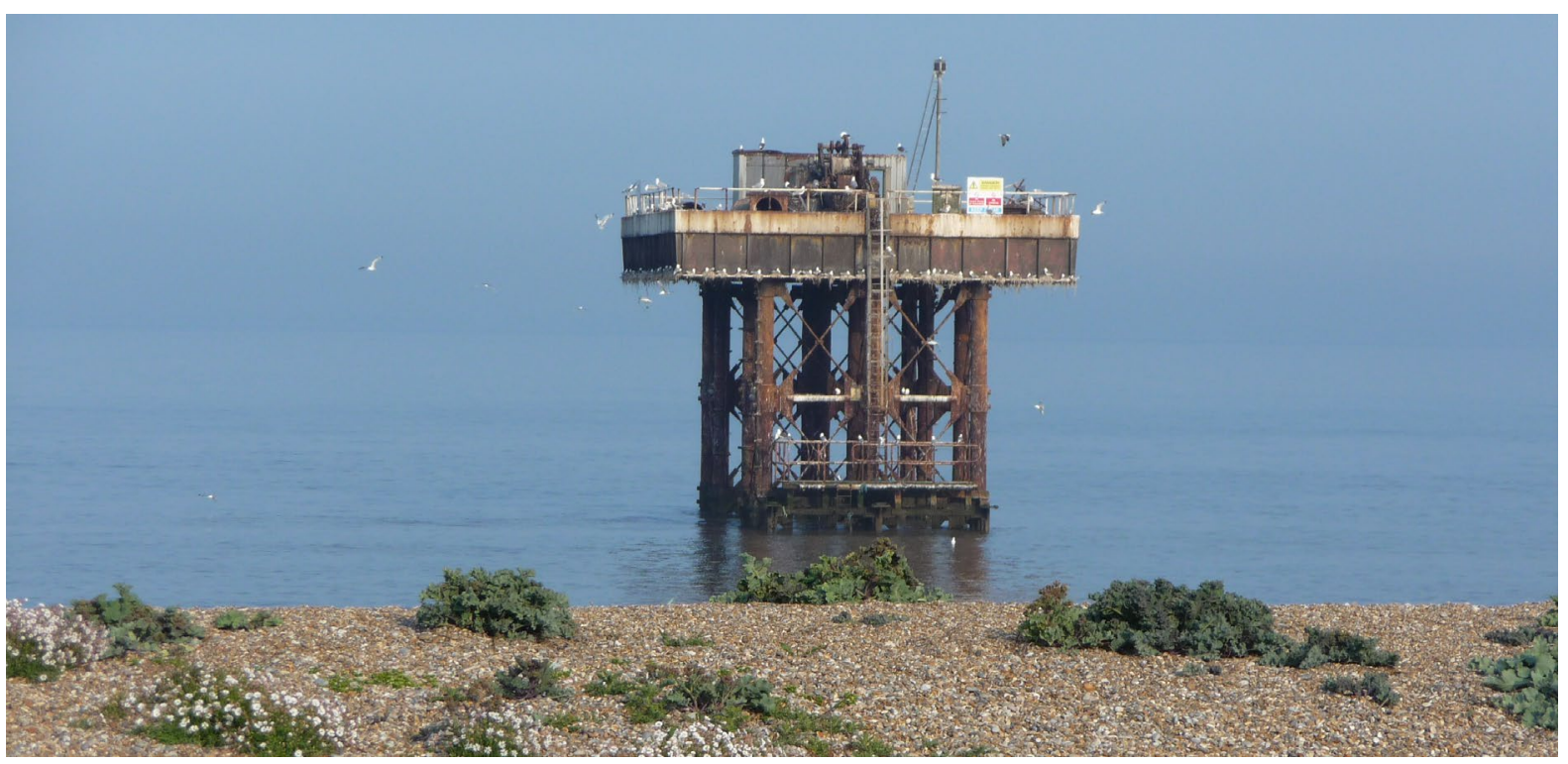

Plate 3 Sizewell B viewed from the RSPB reserve at Minsmere

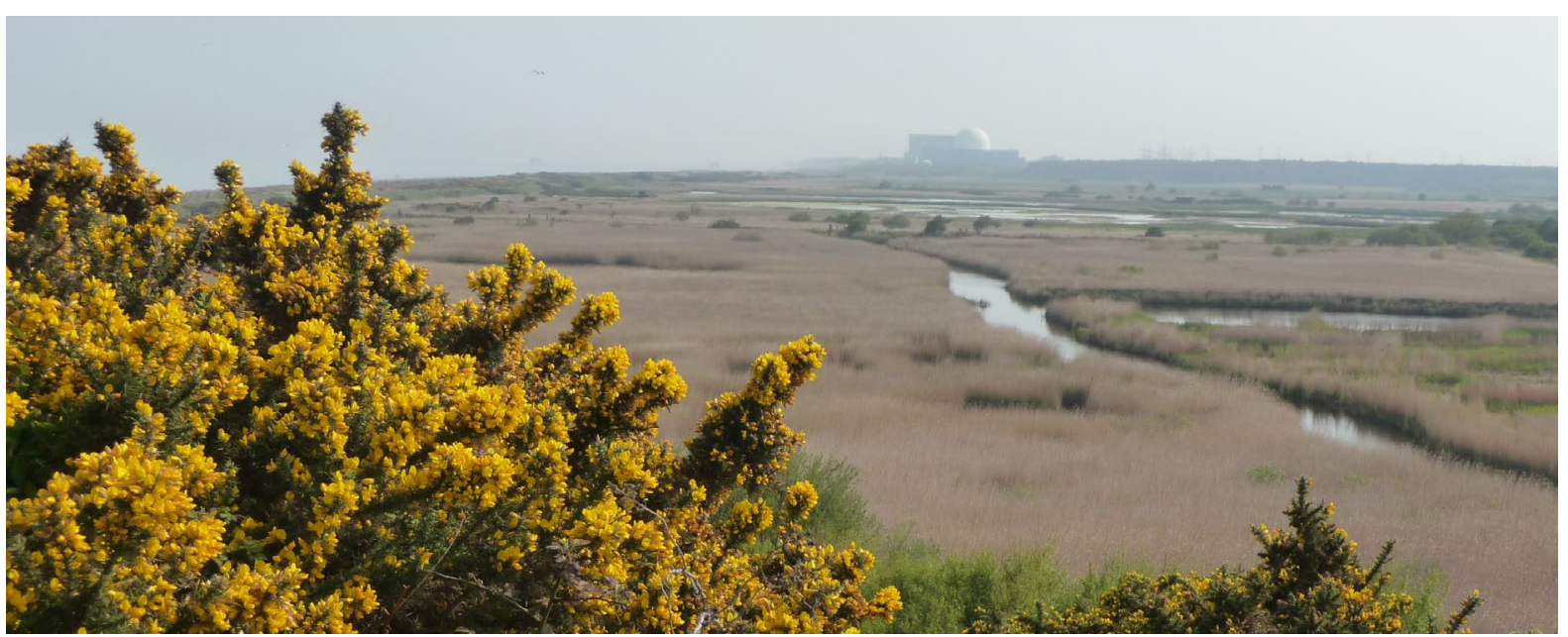

